\title{
First report of Yambean mosaic virus in Brazil
}

\section{Layla de Sá Andrade Medeiros ${ }^{1}$ • Izaías Araújo de Oliveira ${ }^{1}$ - Lorenna Leal Pires ${ }^{1}$ • Elliot Watanabe Kitajima ${ }^{2}$. Gilson Soares da Silva ${ }^{3}$. José Evando Aguiar Beserra Jr ${ }^{1}$ (D)}

Received: 6 May 2019 / Accepted: 11 June 2019 / Published online: 11 July 2019

(C) Australasian Plant Pathology Society Inc. 2019

\begin{abstract}
Potyvirus can cause losses in several important crops worldwide. This study describes the identification of a potyvirus infecting Jack bean plants and causing severe mosaic in Piauí state, Brazil. The virus reproduced original symptoms in mechanically inoculated Jack bean plants. Further molecular and transmission electron microscopy assays enabled the identification of the causal virus as Yambean mosaic virus (YBMV). To the best of our knowledge, this report is the first to describe YBMV in Brazil.
\end{abstract}

Keywords Canavalia ensiformis $\cdot$ Cylindrical inclusions $\cdot$ Jack bean $\cdot$ Potyvirus

The Jack bean (Canavalia ensiformis) is a legume with tropical and subtropical distribution that is used as a green manure for soil enrichment and is commonly used in cattle feed (Suzuki and Alves 2006). Among diseases that occur in Jack beans in Brazil, mosaic has been historically associated with potyviruses, although precise identification at the species level has not been possible because previous studies used less precise techniques and because data on the genomes of these viruses is lacking (Costa et al. 1989; Santos et al. 1990, 1991). In February 2018, Jack bean plants exhibiting mosaic, leaf deformation and blistering symptoms (Fig. 1) were found in the state of Piauí, Brazil. We investigated the aetiology of the disease by amplifying and sequencing two genomic regions ( $\mathrm{CI}$ and $\mathrm{NIb}$ gene) complemented by TEM, identifying the causal agent of mosaic in Jack bean as an isolate of Yambean mosaic virus (YBMV).

The leaf samples of symptomatic Jack beans were collected at the experimental unit $\left(\mathrm{S} 05^{\circ} 2^{\prime} 33.55^{\prime \prime}\right.$ and $\left.\mathrm{W} 42^{\circ} 47^{\prime} 3.08^{\prime \prime}\right)$ of the Department of Plant Science at the UFPI, Teresina,

The sequences reported in this paper have been deposited in the GenBank under accession numbers MK825543, MK825544 and MK829488.

José Evando Aguiar Beserra, Jr evando@ufpi.edu.br

1 Departamento de Fitotecnia, Universidade Federal do Piauí, Teresina, PI 64049-550, Brazil

2 Departamento de Fitopatologia e Nematologia, ESALQ/USP, Piracicaba, SP 13418-900, Brazil

3 Laboratório de Nematologia, Universidade Estadual do Maranhão, São Luís, MA 65001-970, Brazil
Piauí, Brazil. Symptomatic leaves were collected for further analysis by transmission electron microscopy (TEM) and for molecular diagnosis by amplification and sequencing of genome regions. Samples were identified and preserved at $-80{ }^{\circ} \mathrm{C}$. TEM was employed to examine negatively stained leaf extracts (Kitajima 1965) and to observe the cytopathic effects on leaf tissues exhibited by symptomatic Jack bean plants. For direct observation of leaf extract, symptomatic leaves were macerated in the presence of phosphate buffer (0.01 M, pH 7.0), transferred onto carbon-Formvar coated grids and negatively contrasted with uranyl acetate. For ultrastructural analysis by TEM, small fragments of symptomatic leaves of Jack bean were fixed in a glutaraldehyde (2.5\%)/ paraformaldehyde $(2 \%)$ mixture in cacodylate buffer $(0.05 \mathrm{M}, \mathrm{pH}$ 7.2) for several hours, post-fixed with $1 \%$ $\mathrm{OsO}_{4}$, dehydrated in a graded ethanol series, and subjected to infiltration and embedding in the Spurr epoxy resin. The

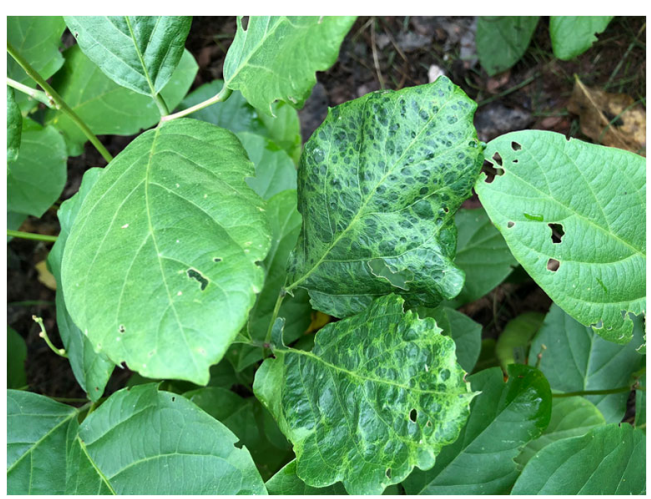

Fig. 1 Symptoms of YBMV on the leaves of naturally infected Jack beans (Canavalia ensiformis) 


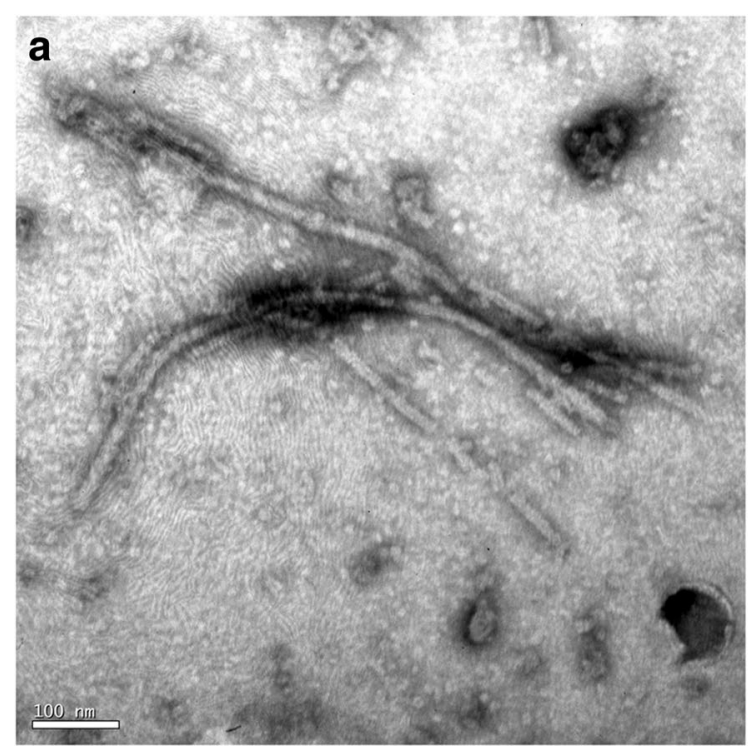

Fig. 2 Transmission electron micrograph of the isolate of YBMV infecting Jack bean (Canavalia ensiformis). a Elongated, flexuous particles present in a negative-stained extract from infected Jack bean leaf. b Typical potyvirus cylindrical inclusions (CI) of type II in

blocks were sectioned in a Leica Ultracut UCT ultramicrotome equipped with a Diatome diamond knife, and 70-100$\mathrm{nm}$-thick sections were collected on 300 mesh copper grids. Sections were contrasted with uranyl acetate and lead citrate and examined in a TEM JEOL 1011. The images were digitally recorded (Kitajima and Nome 1999). Total tissue leaf RNA from symptomatic plants was extracted with the Trizol® reagent (Thermo Fisher Scientific, USA) following the manufacturer's recommendations. The pellets were resuspended in $50 \mu \mathrm{L}$ of ultrapure distilled water free of nucleases. The RNA samples were analysed by $1 \%$ agarose gel

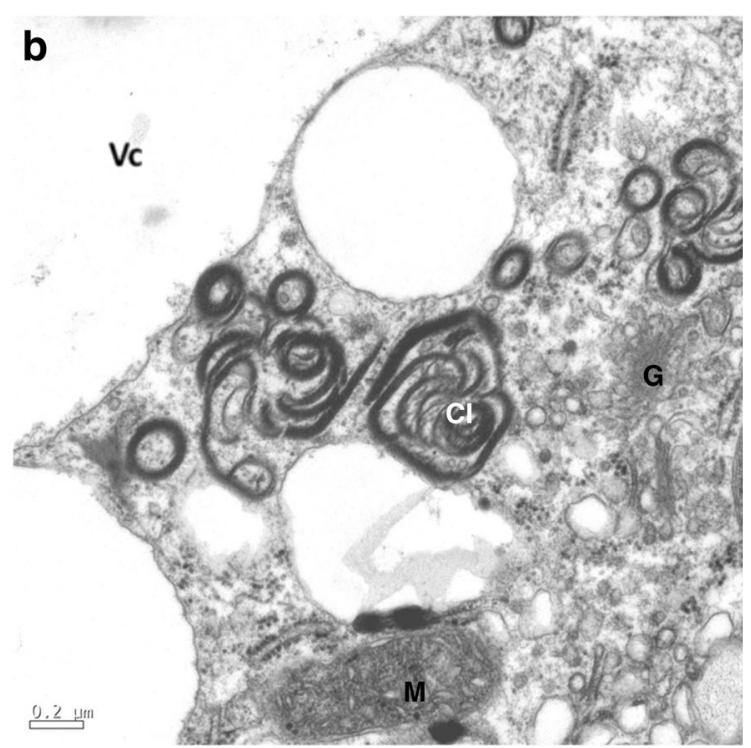

Edwardson's classification formed by groups of scrolls joined in the centre and the absence of lamellar aggregates present in a section of leaf parenchyma of infected Jack bean. G- Golgi complex; M- mitochondria; Vc- Vacuole

electrophoresis in $0.5 \mathrm{x}$ TBE (Tris-Borate-EDTA) buffer, stained with ethidium bromide and visualized under UV light in the UVB transilluminator (Loccus, São Paulo, Brazil). The RNAs were stored at $-20^{\circ} \mathrm{C}$. The reactions to amplify the CI and $\mathrm{NIb}$ genes were performed in two steps. First-strand cDNAs were synthesized using GoScript ${ }^{\circledR}$ reverse transcriptase enzyme (Promega, Madison, WI, USA) according to the manufacturer's recommendations and using CIRev and NIb3R as the initial primers. Polymerase chain reaction (PCR) assays were performed with the universal oligonucleotides CIFord and CIRev (Ha et al. 2008) and the NIb2F and
Fig. 3 Neighbour-joining phylogenetic tree of cylindrical inclusion (CI) protein gene sequences of YBMV isolates (indicated by black diamond) compared with previously reported YBMV and other potyviruses. Analysis was performed with MEGA8 with 1000 replicates of bootstrapping. The isolates from this study are marked $(\bullet)$

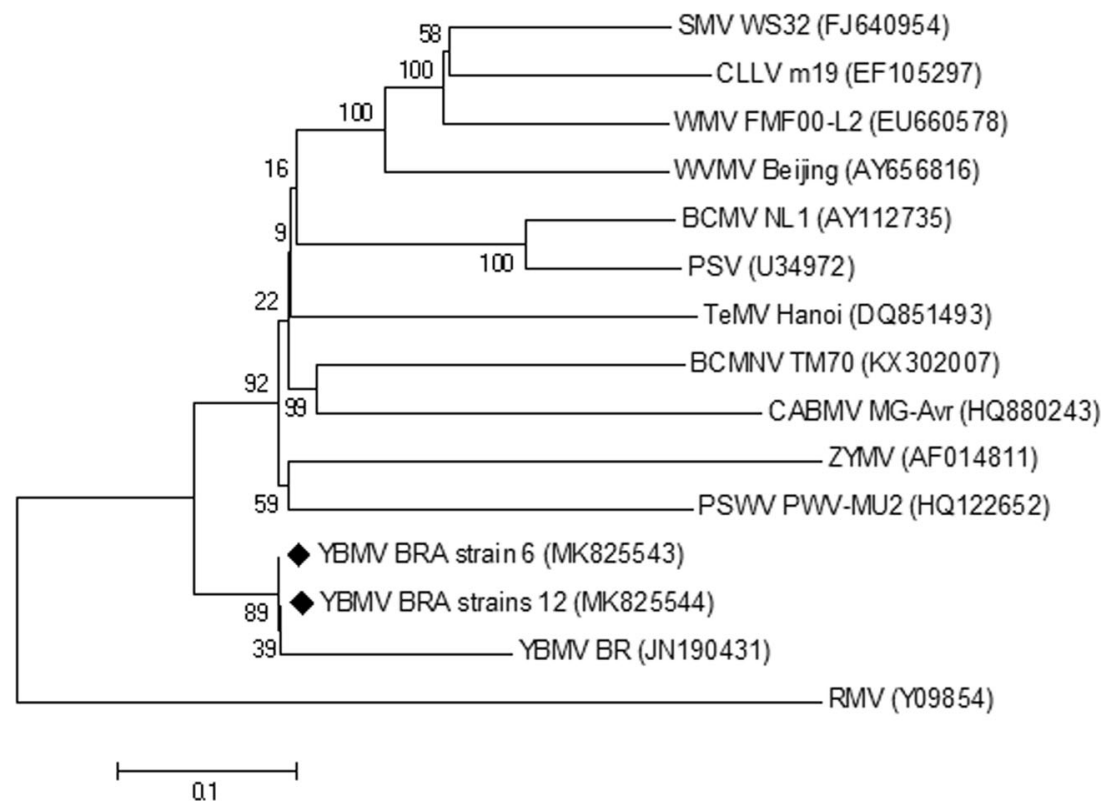


NIb3R (Zheng et al. 2010) of potyviruses. For synthesis of the PCR, the GoTaq ${ }^{\circledR}$ Hot Start Polymerase (Promega, Madison, WI, USA) was used according to the manufacturer's recommendations. Samples were also tested by reverse transcription PCR (RT-PCR) using specific or universal primers for different viruses that incite similar symptoms on legume plants: Cucumber mosaic virus (Kim et al. 2014), Cowpea severe mosaic virus (Brioso et al. 1996), and Cowpea mild mottle virus (Lamas et al. 2017). The reactions were performed in AmpliTherm $®$ thermal cyclers (Axygen). The amplified fragments were purified and sequenced in both directions (forward and reverse) by Macrogen Inc. (Seoul, South Korea). The edited sequences were compared to sequences deposited in GenBank by the BLASTn tool (http://blast.ncbi.nlm.nih.gov/ Blast.cgi). Multiple sequence alignments were generated using the MUSCLE algorithm implemented by the MEGA v.8.0 program (Kumar et al. 2018). The alignments were corrected manually and analysed with the MEGA v.8.0 program using the neighbour-joining method.

Leaf samples from Jack beans plants that were previously confirmed to be infected with only one virus species were mechanically inoculated via buffered plant extract $(0.01 \mathrm{M}$ potassium phosphate, $\mathrm{pH}$ 7.5) and abrasive (carborundum) in five healthy Jack bean plants. The inoculation occurred 20 days after emergence of the seedlings. The plants were cultivated in $2.8 \mathrm{~L}$ pots containing sterile substrate $(70 \%$ soil, $15 \%$ burned rice straw and $15 \%$ cattle manure) and kept in insect-free cages throughout the entire experiment period. Two plants were used as controls.

TEM examination of extracts from symptomatic Jack bean plants revealed the consistent presence of elongated and flexuous particles ca. $13 \mathrm{~nm}$ in diameter and 700-750 nm in length (Fig. 2a). The presence of cylindrical inclusions (Fig. 2b) in the cytoplasm of leaf cells of symptomatic plants suggested that the infection was caused by a member of the genus Potyvirus. Comparisons of the $700 \mathrm{bp}$ and $350 \mathrm{bp} \mathrm{CI}$ and NIb gene amplicon sequences, respectively, with sequences available from GenBank revealed $88 \%$ and $88.26 \%$ identity with YBMV isolated from yam bean plants in Peru (accession number JN190431) (Fuentes et al. 2012) and Indonesia (accession number AB289438) (Damayanti et al. 2008), respectively. These values are above the limit of demarcation of species of potyviruses, that is, $78.3 \%$ and $76.6 \%$ for the genes $\mathrm{CI}$ and $\mathrm{NIb}$, respectively (Addans et al. 2005), according to the International Committee on Taxonomy of Viruses (ICTV), indicating that the potyvirus infecting and causing mosaic in Jack bean in Brazil is an isolate of YBMV. All samples presented negative results for the presence of CMV, CPMMV and comoviruses (data not shown). Phylogenetic analysis using the CI region and including other related potyviruses showed that they formed a wellsupported clade, with the YBMV isolate from Peru (Fig. 3). This report is the first to describe YBMV in natural infections in Brazil. YBMV has probably been detected in the country since the 1980s, but the identification techniques used at the time were not sufficiently accurate for the correct identification of the causal agent, which was tentatively identified as an isolate of a Bean common mosaic virus (BCMV), serologically close to Cowpea aphid borne mosaic virus (CABMV) (Costa et al. 1989), or even as an unidentified species but related to BCMV (Santos et al. 1990, 1991). Additional surveys investigating the natural occurrence of YBMV in Brazil are required to assess its dissemination, since it is known that this virus may cause diseases in cash crops, such as cowpea and tomato (Damayanti et al. 2008).

Acknowledgements IAO is recipient of a CAPES scholarship and JEABJ and EWK are recipients of PQ fellowship from CNPq. Financial support from FAPESP Biota Program 2017/18910-4.

\section{Compliance with ethical standards}

Disclosure of potential conflicts of interest We declare that the authors have no conflicts of interest.

Ethical approval This article does not contain any studies with human participants or animals performed by any of the authors.

\section{References}

Addans MJ, Antoniw JF, Fauquet CM (2005) Molecular criteria for genus and species discrimination within the family Potyviridae. Arch Virol 150:459-479

Brioso PST, Santiago LJM, Anjos JRN, Oliveira DE (1996) Identificação de espécies do gênero comovirus através de "Polymerase chain reaction". Fito Bras 21:219-225

Costa CL, Kitajima EW, Vera LA (1989) Caracterização do vírus da acronecrose da canavalia. Fito Bras 14:115

Damayanti TA, Susilo D, Nurlaelah S, Sartiami D, Okuno T, Mise K (2008) First report of Bean common mosaic virus in yam bean [Pachyrhizus erosus (L.) urban] in Indonesia. J Gen Plant Pathol 74:438-442

Fuentes S, Heider B, Tasso RC, Romero E, Felde TZ, Kreuze JF (2012) Complete genome sequence of a potyvirus infecting yam beans (Pachyrhizus spp.) in Peru. Arch Virol 157:773-776

Ha C, Coombs S, Revill PA, Harding RM, Vu M, Dale JL (2008) Design and application of two novel degenerate primer pairs for the detection and complete genomic characterization of potyviruses. Arch Virol 153:25-36

Kim MK, Jeong RD, Kwak HR, Lee SH, Kim JS, Kim KH, Cha B, Choi HS (2014) First report of Cucumber mosaic virus isolated from wild Vigna angularis var. nipponensis in Korea. Plant Pathology J 30:200-207

Kitajima EW, Nome CF (1999) Microscopia eletrônica em virologia vegetal. In: Do Campo D, Lenardon S L (ed) Métodos para detectar patógenos sistêmicos, IFFIVE/JICA. Córdoba:59-87

Kitajima EW (1965) A rapid method to detect particles of some spherical plant viruses in fresh preparations. J Electron Microsc 14:119-121

Kumar S, Stecher G, Li M, Knyaz C, Tamura K (2018) MEGA 8: Mega $\mathrm{X}$ : molecular evolutionary genetics analysis across computing platforms. Mol Bio Evol 35:1547-1549

Lamas NS, Matos VORL, Alves-Freitas DMT, Melo FL, Costa AF, Faria JC, Ribeiro SG (2017) Occurrence of Cowpea mild mottle virus in common bean and associated weeds in northeastern Brazil. Plant Dis $101: 1828$ 
Santos OR, Costa CL, Kitajima EW, Meyer MC, Ramagem RD (1990) Propriedades físicas e biológicas do vírus do mosaico da canavalia. Fito Bras 15:132

Santos OR, Costa CL, Kitajima EW, Meyer MC (1991) Propriedades químicas e sorológicas do vírus do mosaico da canavalia. Fito Bras 16:27
Suzuki LEAS, Alves MC (2006) Fitomassa de plantas de cobertura em diferentes sucessões de culturas e sistemas de cultivo. Bragantia 65: $121-127$

Zheng L, Rodoni BB, Gibbs MJ, Gibbs AJ (2010) A novel pair of universal primers for the detection of potyviruses. Plant Pathol 59:211-220 